\title{
TITLE:
}

\section{A CHECK LIST OF ECHINOIDS FOUND IN THE KII REGION}

$\operatorname{AUTHOR}(S)$ :

Utinomi, Huzio

CITATION:

Utinomi, Huzio. A CHECK LIST OF ECHINOIDS FOUND IN THE KII REGION. PUBLICATIONS OF THE SETO MARINE BIOLOGICAL LABORATORY 1954, 3(3): 339-358

ISSUE DATE:

1954-05-30

URL:

http://hdl.handle.net/2433/174487

RIGHT: 


\title{
A CHECK LIST OF ECHINOIDS FOUND IN THE KII REGION ${ }^{13}$
}

\author{
HUzio UTINOMI \\ Seto Marine Biological Laboratory, Sirahama \\ With one Text-figure
}

\section{Introduction}

The Echinoderm fauna of the Kii region, Middle Japan, has never been made the object of special investigation. A number of species of the Echinoidea have hitherto been recorded from various places along the Kii Peninsula, but such records are scattered in various works dealing with the embryological or ecological subject, and are, naturally, not all of them quite reliable taxonomically.

Whereas recently a preliminary record on the regular-formed echinoids of Wakayama Prefecture has been given by SARAGUCHI, basing on the identification by the late echinologist Hayato IKEDA, in "Kisyû Dôsyokubutu", vol. II, no. 2 (1935), no special work on this group has been given till now, excepting my two short mimeographed papers. I therefore thought that a catalogue of all the known echinoids hitherto recorded or described from the Kii region would be of some value to students interested to these animals.

The echinoids given in the present paper amount to 53 species in all, of which 33 belong to the Regularia and 20 to the Irregularia. Among them, 45 species are seen in materials at hand and thus their occurrence has been confirmed by myself. For minor records and detailed structure of species listed in this paper, the student is further referred to the complete and excellent work of MoRTEnsEn's "Monograph of the Echinoidea" (1928-1951).

As might be expected from the geographical position, the echinoid fauna of the Kii region, especially in the southern part, is characterized by its pronounced tropical faces and richness in forms. Although no new species is represented in the whole collection, there are some rare and interesting tropical forms, such as Astropyga radiata, Pseudoboletia maculata, Diadema Savignyi, Echinothrix calamaris, Echinothrix diadema, Clypeaster reticulatus and Peronella minuta, all of which have not hitherto been recorded from Japan proper with certainty. Besides, the following six regular-

1) Contributions from the Seto Marine Biological Laboratory, No. 225.

Publ. Seto Mar. Biol. Lab., III (3), 1954. (Article 26) 
formed species which have apparently the northern limit in the Kii region are found rather commonly in the littoral region: Eucidaris metularia, (?) Plococidaris verticillata, Stomopneustes variolaris, Tripneustes gratilla, Parasalenia gratiosa and Echinostrephus aciculatus. Only one species Echinometra Mathaei, which is very common here, further extends its range to the southern end of the Izu Peninsula and Bôsô Peninsula $\left(139^{\circ} 50^{\prime} \mathrm{E}, 35^{\circ} \mathrm{N}\right)$ but not to the interior of the Sagami Sea; it occurs, however, very scarcely there. Another peculiar species, Colobocentrotus Mertensii is known only to occur at Hatizyô Island $\left(139^{\circ} 50^{\prime} \mathrm{E}, 33^{\circ} 05^{\prime} \mathrm{N}\right)$ in the east, but not so far found at the above localities in Honsyn̂.

In bays or inlets along the coast of Kii Peninsula, irregular-formed species, such as Schizaster lacunosus, Echinocardium cordatum, Peronella minuta, Peronella japonica and Fibularia acuta, are collected by dredging everywhere rather commonly.

In preparing this report, Dr. S. KaWAGUTi (Okayama), Mr. S. SAKaGUCHI (Wakayama), Mr. M. Ozaki (Minabe), Mr. H. OGaWA (Sioncmisaki) and Mr. S. YАмАмото (Sirahama) assisted on various occasions in collecting the material. Their help is herewith gratefully acknowledged, as is that of Dr. S. NisIYAMa of Simane University and Mr. A. MoRishITA of Kyoto University for identifying some specimens and also procuring literature.

\section{REGULARIA}

\section{Order CIDAROIDEA}

Family Cidaridae GRAY

\section{Goniocidaris (Petalocidaris) biserialis (DöDERLEIN). (I, p. 173) ${ }^{1)}$}

Syn. Stephanocidaris biserialis, DöDERLEIN, 1885, p. 80 .

Cidaris (Goniocidaris) biserialis, YOSHIWARA, 1898, p. 248, 1905, Pl. III-3, 4, 5, 6.

Nom. Jap. Togezao-uni.

.Material examined. Off Minabe, 100-200 m. 33 specimens (No. E-22, E-48).2) Off Seto. 1 specimen (No. E-41).

Range. Known only from Japanese waters, from Sagami Sea to off Kagosima Bay and also from off Tango (Japan Sea), in depths of ca. 70 to 360 meters.

\section{Goniocidaris (Discocidaris) mikado (DÖDERLEIN). (I, p. 178)}

Syn. Discocidaris (Cidaris) mikado, DÖDERLEIN, 1885, p 8.

Cidaris (Goniocidaris) mikado, YOSHIWARA, 1898, p. 247, 1905, Pl. III-1, 2.

1) Numbers in parentheses refer to MORTENSEN's Monograph.

2) Register number of specimens stored in the collection of the Seto Marine Biological Laboratory. 
Nom. Jap. Mikado-uni.

Material examined. Off Minabe, 100-200 m. 17 specimens (No. E-38, E-49).

Range. Known only from Japanese waters, from Sagami Sea to off Goto Islands, in depths of ca. 150 to 700 meters.

3. Stereocidaris (Phalacrocidaris) japonica (DÖDERLEIN). (I, p. 280)

Syn. Dorocidaris japonica, DöDERLEIN, 1885, p. 4.

Cidaris (Stereocidaris) japonica, DÖDERLEIN, 1887, p. 6 ; YOSHIWARA, 1898, p. 146, 1904, P1. I-4, 5.

Cidaris (Stereocidaris) tenuispinus, YOSHIWARA, 1898a, p. 57, 1898, p. 147, 1904, P1. I-8, 9, 10.

Anomocidaris tenuispina, A. AGASSIZ \& H. L. CLARK, 1907, p. 30.

Nom. Jap. Hutozao-uni.

Collecting record. Seto (KoMAI \& IKARI, 1929, p. 121, as Anomocidaris tenu spina).

Range. Known only from Japanese waters, from off Kyusyu to Tugaru Strait, in depths of ca. 13 to 700 meters.

\section{Eucidaris metularia (LAMARCK). (I, p. 386)}

Syn. Cidaris (Dorocidaris) metularia, YOSHIWARA, 1898, p. 145, 1904, P1. I-1.

Nom. Jap. Matukasa-uni. (UTinomi)

Collecting record. Sué, Kii-ôsima (SakaGuchi, 1935, p. 14). Minabe (Utinoma, 1952, p. 13).

Material examined. Seto, at low tide. 2 specimens (No. E-42). Sio-no-misaki, at low tide. 1 specimen (H. OGAWA coll.).

Range. Widely distributed all over the Indo-Pacific. This is strictly a littorai form, but known as occurring down to ca. $570 \mathrm{~m}$.

5. Plococidaris verticillata (LAMARCK). (I, p. 428)

Syn. Phyllacanthus verticillata, A. AGASSIZ \& H. L. CIARK, 1907, p. 187.

Prionocidaris verticillata, H. L. CLARK, 1921, p. 149.

Cidaris (Leiocialaris) verticillata, YosHIWARA, 1900, p. 147, 1904, Pl. I-6.

Nom. Jap. Husizao-uni. (nom. nov.)

Collecting record. Sué, Kii-ôsima (SaKaGuchi, 1935, p. 14).

Range. Widely distributed all over the Indo-Pacific, from Zanzibar to Samoa and also to Southern Japan. According to OHsHIMA (1947), this species is very common on the coral reef of the Ryukyu Islands, but I have failed to find on the Kii coast.

6. Prionocidaris baculosa var. annulifera (LAMARCK). (I, p. 437)

Syn. Leiocidaris baculosa, DöDERLEIN, 1887, p. 23. 
Leiocidaris annulifera, DÖDERLEIN, p. 24.

Phyllacanthus baculosa, A. AGASSIZ \& H. L. CIARK, 1907, p. 15.

Cidaris (Leiocidaris) baculosa, YoshIWARA, 1900, p. 147, 1904, PI. I-11, II-1.

Nom. Jap. Nokogiri-uni. (UTINOMI)

Collecting record. Seto (KomaI et al.; 1927, p. 295; KomaI \& IKARI, 1929, p. 121, as Cidaris baculosa). Minabe (Uтіnomi, 1952, p. 13).

Material examined. Seto, 25-30 m. 2 young specimens (No. E-19). Susami. 4 specimens (No. E-21). Off Tonda, $50 \mathrm{~m} .3$ specimens (No. E-56). Off Kusimoto. One large specimen (No. E-64), $49 \mathrm{~mm}$ in diameter of test and $95 \mathrm{~mm}$ long in longest spine.

Range. Malay Archipelago to Japan, as far north as Sagami Sea, in depths of $0-$ ca. $250 \mathrm{~m}$. This is often taken by shore seine or lobster-net in the Kii region. The young specimen with short spines resembles the above-mentioned littoral form Eucidaris metularia, so that RoXAs (1928) and HAYASAKA (1948) have mistaken as this species.

Associate. A pedurculate cirriped Trilasmis eburnea HINDs was once found attached to the spine (HrRo, 1938, p. 477).

\section{Order LEPIDOCENTROIDA}

\section{Family Echinothuridae Wyv. ThOMSON}

\section{Calveriosoma gracile (A. AGASSIZ). (II, p. 227)}

Syn. Asthenosoma gracile, A. AGASSIZ, 1881, p. 89.

Asthenosoma longispinum, YoseIWARA, 1897, p. 5, 1898, p. 249, 1905, Pl. III-8, 9.

Nom. Jap. Harinaga-hukuro-uni. (OHshima)

Material examined. Off Tonda, $80-100 \mathrm{~m}$. One specimen, $130 \mathrm{~mm}$ in diameter (No. E-61).

Range. Known only from the Philippines, off Halmahera and from Japan (Sagami Sea), in depths of ca. $160-800 \mathrm{~m}$.

8. Asthenosoma Ijimai Yoshrwara. (II, p. 288)

Nom. Jap. Ijima-hukuro-uni. (OHSHIMA)

Collecting record. Seto (Hiraiwa, 1932, p. 65).

Material examined. Off Tonda, $80-100 \mathrm{~m}$. One specimen, $135 \mathrm{~mm}$ in diameter (No. E-62).

Range. Japan (Sagami Sea, Amakusa) to the Moluccan Sea, in depths of ca. $20-120 \mathrm{~m}$. 


\section{Order STIRODONTA}

Family Stomopneustidae MORTENSEN

9. Stomopneustes variolaris (LAMARCK). (II, p. 507)

Nom. Jap. Kuro-uni. (UTiNomi)

Collecting record. Kii-ôsima (SAKAGuchi, 1935, p. 14). Tôsima, Tanabe Bay (UTINOMI, 1949, p. 55).

Material examined. Tôsima, at low tide. 3 specimens, 21 to $55 \mathrm{~mm}$ in diameter (No. E-44).

Range. Indo-Pacific, from East Africa to Samoa and to southern Japan in the north. MoRtensEn (1938) saw a specimen from Izu-ôsima in Sagami Sea, but he says that "it does not appear to occur as a rule in southern Japanese seas."

\section{Family Arbaciidae GRAY}

10. Coelopleurus maculatus A. AGASsIZ \& H. L. ClARK. (II, p. 631)

Syn. Coelopleurus maillardi A. AGASSIZ, 1881, p. 60. (pro parte)

Nom. Jap. Azuma-uni. (OHswima)

Material examined. Off Minabe, $100-200 \mathrm{~m}$. One spine only (No. E-39) (UTINOMI, 1952, p. 14).

Range. Kei Islands to Japan, as far north as the Korea Strait and Sagami Sea, in depths of ca. 70 to 360 meters.

\section{Order AULODONTA \\ Family Pedinidae (Pomel) Gregory}

11. Caenopedina mirabilis (DÖDERLEIN). ( $\mathrm{III}_{1}$, p. 99)

Syn. Hemipedina mirabilis, DöDERLEIN, 1885, p. 24 ; YOSHIWARA, 1900, p. 330, 1905, PI. V-5.

Nom. Jap. Otome-uni. (nom. nov.)

Collecting record. Off Hino-misaki (originally spelled as Hiro Misaki), $191 \mathrm{fms}$. ( $=344 \mathrm{~m})$ (CLARK, 1912, p. 221).

Material examined. Off Minabe, $100-200 \mathrm{~m}$. 6 specimens, $12-18 \mathrm{~mm}$ in diameter (No. E-24) (Utinomi, 1952, p. 15).

Range. Known only from Japan, from off Kagosima Gulf to off Kinkasan Light, in depths of ca. 21 to 360 meters. 


\section{Family Diadematidae Peters}

\section{Astropyga radiata (LESKE). ( $\mathrm{III}_{1}$, p. 187) (Fig. 1A)}

Syn. (?) Astropyga pulvinata YOSHIWARA, 1905, P1. VI-7, 8, 9.

Nom. Jap. Akaoni-gaze. (nom. nov.)

Collecting record. Seto (KomaI et al., 1927, p. 295, as Astropyga?).

Material examined. Off Tonda, depth unlabelled. 2 specimens, both $160 \mathrm{~mm}$ in diameter and $55 \mathrm{~mm}$ in height (No. E-57, E-60). Recently two additional specimens were obtained alive from off the Laboratory, but unfortunately they were afterwards so putrefied that one could hardly preserve in alcohol due to bad fixisation.

Range. Widely distributed all over the Indo-Pacific region, from East Africa to Hawaii in the east and to Japan in the north, in depths of ca. 2 to 60 meters. No locality is given by YoshIWARA for his "Astropyga pulvinata", which is probably this $A$, radiata.

A

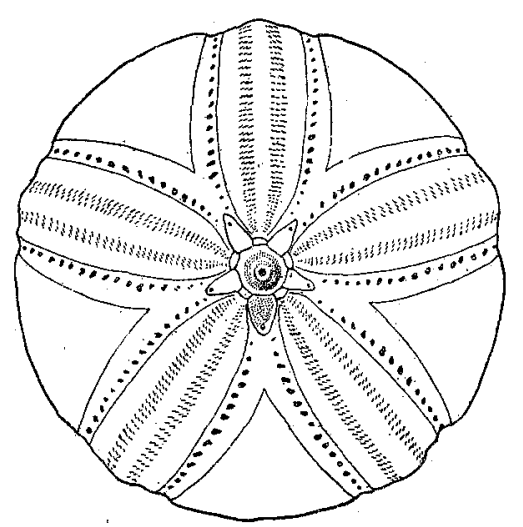

B

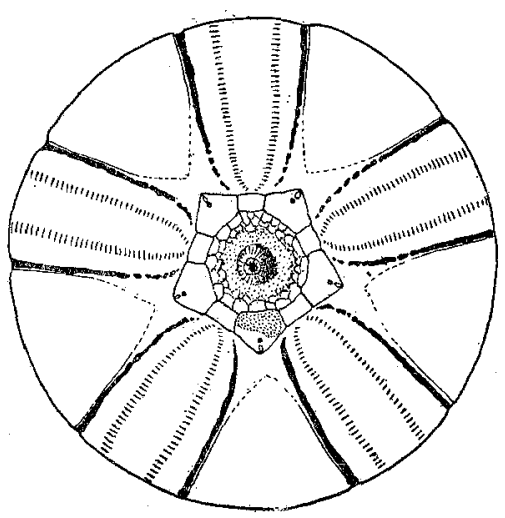

Fig. 1. Aboral side of test of two large diadematids, Astropyga radiata (A) and Chaetodiadema japonicum (B), showing the arrangement of pore-pairs and blue spots.

13. Chaetodiadema japonicum MORTENSEN. (III, p. 223) (Fig. 1B)

Syn. Astropyga sp., YoshiwARA, 1905, Pl. VI-5, 6.

(?) Astropyga radiata, YoSHIWARA, 1905, P1. VI-3, 4. (non LESKE).

Nom. Jap. Yawara-gaze. (nom. nov.)

Material examined. Off Tonda, $80-100 \mathrm{~m}$. 3 specimens, 65 to $90 \mathrm{~mm}$ in diameter (No. E-58).

Range. Known only from Sagami Sea $(50 \mathrm{~m})$ and off Goto Islands $(135 \mathrm{~m})$. 
14. Diadema setosum (LESKE). (III, p. 256)

Syn. Centrechinus setosus, H. L. CLARK, 1921, p. 146.

(?) Diadema Clarki, IKEDA, 1939a, p. 165.

Nom. Jap. Gangaze.

Collecting record. Seto (KomaI et al., 1927, p. 295; KoMAI \& IKARI, 1929, p. 120 ; SAKaguchi, 1935, p. 16; ONODA, 1936, p. 648).

Material examined. Seto. (No. E-31, E-59) and many living specimens.

Range. Widely distributed all over the Indo-Pacific, from East Africa to Australia and Polynesian Islands and to Japan (Misaki) in the north. Mainly littoral, but goes at least down to ca. $70 \mathrm{~m}$.

Breeding. Usually late in summer, from August to September at Seto.

Parasite. A gastropod Rosenia tokiokai HABE is occasionally found on the peristome (HABE, 1952, p. 82).

\section{Diadema Savignyi (Audouin) Michelin. ( $\mathrm{III}_{1}$, p. 265)}

Nom. Jap. Aosuzi-gangaze. (nom. nov.)

Material examined. Seto. 2 specimens (No. E-37) (UTinomi, 1949, p. 56). Common in shallow waters at Seto, but not so abundant as $D$. setosum.

Range. Indo-Pacific region, from East Africa to Easter Island in the east and to southern Japan. Exact locality in Japan proper is not so far given, excepting its occurrence in Ogasawara and Ryukyu Islands.

16. Echinothrix calamaris (PALLAS). (III, p. 285)

Nom. Jap. Tokkuri-gangaze-modoki. (nom. nov.)

Material examined. Seto, at low tide. 3 specimens, $17-32 \mathrm{~mm}$ in diameter (No. E-65) and many living specimens.

Range. Indo-Pacific region, from Red Sea to Hawaii and to southern Japan. Strictly a littoral form, usually living on the coral reef in tropical seas (NISIYAMA, 1942). This species, like $E$. diadema, is hitherto known from Ogasawara Islands (after Yoshiwara), Ryukyu Islands (after OHsHima), and Tokara Islands (ToKIoKA, 1953). In the vicinity of the Laboratory, both species of Echinothrix are very common in tide pools, but living deeply concealed underside the rock-cliff in daytime. Anyone has not been awared of its occurrence in common, till Dr. KAWAGUTI collected for the first time at night spring-tide ebb in December of 1952.

17. Echinothrix diadema (LINNÉ). (III , p. 290)

Syn. Echinothrix furcarum, YOSHIWARA, 1898, p. 330, 1905, P1. VI-1, 2.

Nom. Jap. Gangaze-modoki ${ }^{1)}$. (OHshima)

1) Formerly applied to Echinothrix calamaris. 
Material examined. Seto., at low tide, 6 specimens, $18-30 \mathrm{~mm}$ in diameter (No. E-66) and many living specimens.

Range. The same as E. calamaris.

Parasite. A gastropod Rosenia tokiokai HABE is found on the test.

\section{Order CAMARODONTA}

\section{Family Temnopleuridae A. AGAssiz}

18. Temnopleurus toreumaticus (KLEIN). ( $\mathrm{III}_{2}$, p. 76)

Nom. Jap. Sansyô-uni.

Collecting record. Wakanoura (Yoshiwara, 1898, p. 439). Kada, 10-20 m (SAKAGUChI, 1935, p. 16, as var. perezi). Goza, $3 \mathrm{~m}$ (ONODA, 1936, p. 646). Yurawan, $12 \mathrm{~m}$ (HABE et al., 1946, p. 8).

Material examined. Seto. 7 specimens, $26-40 \mathrm{~mm}$ in diameter (No. E-34).

Range. Widely distributed all over the Indo-Pacific region, from East Africa to Japan, in depths of $0-\mathrm{ca} .45 \mathrm{~m}$. In the Kii Peninsula this species is apparently common in the northern part but becomes scarce southwards.

Breeding. Summer, from June to July at Toba (after Sugryama), while from July to August at Goza (after ONODA).

19. Temnopleurus (Toreumatica) Reevesii (GRAY). ( $\mathrm{III}_{2}$, p. 92)

Syn. Temnopleurus Reynaudi, DödERLEIN, 1885, p. 18 ; YoSHIWARA, 1898, p. 440, 1906, P1. VIII-1, 2, 3, 4 .

Nom. Jap. Hari-sansyô-uni. (nom. nov.)

Collecting record. Tanoura and Wakasaura, (YoshiWARA, 1898, p. 440, as $T$. Reynaudi). Kada (SAKaguchi, 1935, p. 15).

Material examined. Seto. 8 specimens, $12-30 \mathrm{~mm}$ in diameter (No. E-45). This species is rather common hereabout at low tide than $T$. toreumaticus.

Range. Widely distributed over the Indo-Pacific, from East Africa to northern Japan (Hakodate), in depths of 0-ca. $565 \mathrm{~m}$.

Breeding. July at Seto.

20. Temnopleurus (Toreumatica) apodus (A. Agassiz \& H. L. ClarK). (III, p. 99)

Syn. Genocidaris apoda, H. L. CLARK, 1912, p. 297.

Nom. Jap. Kotubti-sansyô-uni. (nom. nov.)

Material examined. Tanabe Bay, $12-30 \mathrm{~m} .12$ specimens, $6-10 \mathrm{~mm}$ in diameter (No. E-17). 
Range. Japan (formerly from off Gotô Islands and Sagami Sea), Malay Archipelago to Pemba Strait (East Africa), in depths of ca. 12 to 500 meters.

\section{Salmaciella Dussumieri (L. AGASSIZ \& DESOR). (III ${ }_{2}$, p. 139)}

Syn. Salmacis Dussumieri, A. AGAssiz, 1881, p. 113.

Salmacis lactea, DöDERLEIN, 1885, p. 22 ; YOSHIWARA, 1900, p. 441, 1906, P1. VIII-13, $14,15,16$.

Nom. Jap. Nisiki-uni. (nom. nov.)

Collecting record. Kada, 10-20 m (SAKAGUCHI, 1935, p. 15, as Salmacis dussumieri).

Range. Distributed from Ceylon to Torres Strait and to Japan (Kagosima), in depths of ca. 10 to 180 meters.

22. Mespilia globulus (LINNÉ). (III, p. 177)

Syn. Mespilia levituberculatus, YosHIWARA, 1898a, p. 58, 1900, p. 442, 1906, P1. VIII-20, 21, $22,23$.

Salmacopsis pulchellimus, YoshiWARA, 1898a, p. 59, 1900, p. 441.

Nom. Jap. Kosidaka-uni.

Collecting record. Seto (KomaI et al., 1927, p. 295; KomaI \& IKARI, 1929, p. 120; ONODA, 1936, p. 637). Kii coast (Sarsaguchi, 1935, p. 15).

Material examined. Seto. 5 specimens (No. E-29) and many living specimens. Very abundant all along the Kii coast.

Range. Distributed all over the Malayan waters and southern Japan, as far north as Bôsô Peninsula, from the littoral to ca. $60 \mathrm{~m}$.

Breeding. Summer, usually in July at Seto and more or less later than that of Anthocidaris crassispina.

23. Temnotrema sculptum A. AGAssiz. (III ${ }_{2}$, p. 249)

Syn. Pleurechinus variegatus, MORTENSEN, 1904, p. 84.

Nom. Jap. Hime-uni. (nom. nov.)

Collecting record. Kada, deep bottom (SAkAGuchr, 1935, p. 16).

Material examined. Seto. 2 specimens, $14-15 \mathrm{~mm}$ in diameter (No. E-20). Kada. 6 specimens, $12-14 \mathrm{~mm}$ in diameter (No. E-26).

Range. Known only from Japanese waters, from Formosa Channel to Mutu Bay, in depths of $0-$ ca. $500 \mathrm{~m}$.

Parasite. A Mucronalia-like gastropod is found (MORTENSEN, 1943, p. 251).

Family Toxopneustidae TroscheL

24. Toxopneustes pileolus (LAMARCK). $\quad\left(\mathrm{III}_{2}\right.$, p. 472$)$ 
Nom. Jap. Rappa-uni.

Collecting record. Seto (Komai et al., 1927, p. 295; KomaI \& IKARI, 1929, p. 120). Goza (ONOdA, 1936, p. 644). Kii coast (SAKAGUCHI, 1935, p. 15).

Material examined. Seto. 5 specimens (No. E-32, E-55) and many living specimens. Kada. 2 specimens (No. E-36). Very common all along the Kii coast.

Range. Widely distributed all over the Indo-Pacific region, from East Africa to Fiji and to Japan, as far north as Sagami Sea. From the littoral down to ca. $90 \mathrm{~m}$.

Breeding. Early summer, from April to July at Seto and from May to August at Goza (after ONODA).

Commensal. A platyctenid ctenophore Coeloplana echinicola TANAKA is rarely found at Seto (TANAKA, 1932). No parasitic gastropod is found.

25. Tripneustes gratilla (LINNE). ( $\left(\mathrm{III}_{2}\right.$, p. 500)

Syn. Hipponö̈ variegata, DöDERLEIN, 1885, p. 27 ; YoshIWARA, 1900, p. 386, 1906, Pl. XIII$9,10,11,12$.

Nom. Jap. Sirahige-uni.

Collecting record. Seto (KomaI et al., 1927, p. 295; KomaI \& IKARI, 1929, p. 121, as T. grabella; ONODA, 1936, p. 647). Kii coast, further south than Tanabe (SAKAguchi, 1935, p. 15).

Material examined. Seto. One specimen (No. E-53) and many living specimens. Very common in the southern part of Kii coast.

Range. Widely distributed all over the Indo-Pacific region, from East Africa to Australia, Hawaii and to southern Japan, as far north as Kii Peninsula. From the littoral to ca. $75 \mathrm{~m}$.

Breeding. Summer, from July to August.

Parasite. A Balcis-like gastropod is found on the test.

26. Pseudoboletia maculata Troschel. (III, p. 532)

Nom. Jap. Madara-uni. (nom, nov.)

Material examined. Seto, at low tide. 4 specimens, $45-60 \mathrm{~mm}$ in diameter (No. R-62).

Range. Known from Ceylon, the Philippines, Banda and Timor Seas, in depths of ca. $20-70 \mathrm{~m}$. Its occurrence in Japan has not been recorded as yet.

27. Pseudocentrotus depressus (A. AGASsIZ). ( $\mathrm{III}_{2}$, p. 541)

Nom. Jap. Aka-uni or Hirata-uni.

Collecting record. Seto (Komai et al., 1927, p. 295; KomaI \& IKari, 1929, p. 120). Kada (Saraguchi, 1935, p. 15). Goza (OnODA, 1936, p. 649).

Material examined. Seto. 11 specimens (No. E-16,27,33) and many living 
specimens. Kada. 5 specimens (No. E-25).

Range. Known only from southern Japan, from Mutu Bay to Amakusa, from the littoral to ca. $5 \mathrm{~m}$.

Breeding. Later in autumn, from October to December.

Parasite. Three gastropods, Balcis akauni HABE, Rosenia castanea (DALL) and Rosenia yamamotoi $\mathrm{HABE}$ are known to live on this species, the last one occurring usually on the young form (HABE, 1952, p. 78, 81).

\section{Family Strongylocentrotidae GREGORY}

28. Hemicentrotus pulcherrimus (A. AGASSIZ). (III, p. 248)

Syn. Sphaerechinus pulcherrimus, DöDERLEIN, 1885, p. 15 ; YOSHIWARA, 1900, p. 383, 1906, PI. XIII-1, 2, 3, 4 .

Strongylocentrotus pulcherrimus, H. L. CIARK, 1908, p. 304 ; OHSHIMA, 1947, p. 585.

Nom. Jap. Bahun-uni.

Collecting record. Seto (Komai et al., 1927, p. 295; KomaI \& IKari, 1929, p. 120; Onoda, 1936, p. 649). Kada (SAKaguchi, 1935, p. 15). Toba, Prov. Sima (ONODA, 1938, p. 1). All recorded as Strongylocentrotus pulcherrimus.

Material examined. Seto. 15 specimens (No. E-23, E-47) and many living specimens. Kada. 15 specimens (No. E-54).

Range. Known only from Japan, from Hakodate to Kagosima, in depths of 0-ca. $45 \mathrm{~m}$.

Breeding. Winter, from January to April at Sugasima (after Sugryama), while at Seto rather later, from March to April.

\section{Family Parasaleniidae MORTENSEN}

29. Parasalenia gratiosa A. AGAssiz. ( $\mathrm{III}_{3}$, p. 269)

Nom. Jap. Nagauni-modoki. (Ohshima)

Collecting record. Goza, Katuura, Seto (ONOdA, 1938, p. 9); Seto (UTINomi, 1949 , p. 56).

Material examined. Seto, at low tide. 5 specimens, $17-30 \mathrm{~mm}$ in long diameter (No. E-46).

Range. Widely distributed all over the Indo-Pacific region, from Zanzibar to Palmira Islands and also to southern Japan, from the littoral to ca. 70 meters. At the Kii coast, it occurs rather commonly on the shore rock, together with Echinometra Mathaei. MORTENSEN refers the Japanese specimens to his var. boninensis mainly with reference to the slenderness of primary spines. This determination may be reserved in future research. 


\section{Family Echinometridae GRAY}

30. Echinostrephus aciculatus A. AgASSIZ. (III, p. 306)

Nom. Jap. Tawasi-uni. (UTINomI)

Collecting record. Seto (ONODA, 1936, p. 646, as Echinostrephus moralis; UTINOMI, 1949, p. 56).

Material examined. Seto, 20 specimens, $20-45 \mathrm{~mm}$ in diameter (No. E-18, 28, 43) and many living specimens.

Range. Distributed in the Indo-Pacific, from Hawaii to Sulu Islands and to southern Japan (Seto), from the littoral to ca. $50 \mathrm{~m}$.

This species is commonly found, each invariably buried in a hole on the surfwashed or sublittoral rockface, but often dredged from the bottom of the bay. Probably it seems to be able to creep out of the hole for feeding at any time as confirmed in my field observation at night low tide.

Breeding. July at Seto.

31. Anthocidaris crassispina (A. AGASSIZ). ( $\mathrm{III}_{3}$, p. 328)

Syn. Strogylocentrotus tuberculatus, DöDERLEIN, 1885, p. 19; YOSHIWARA, 1900, p. 381, 1906, PI. XI-1, 2.

Heliocidaris crassispina, H. L. CLARK, 1912, p. 350; OHSHIMA, 1947, p. 586.

Nom. Jap. Murasaki-uni.

Collecting record. Seto and other localities in Kii Province (KomaI et al., 1927, p. 295 ; Komai \& IKari, 1929, p. 120; OnOdA, 1931, p. 103, 1933, p. 159 ; SAKaGuchi, 1935, p. 14, all as Heliocidaris crassispina). Wakanoura (YosHIWARA, 1900, p. 381, as Strongylocentrotus tuberculatus).

Material examined. Seto. 5 specimens (No. E-51) and many living specimens.

Range. Very common all around the southern Japanese coast, from Kyusyu to Tokyo Bay. IKEDA (1940) records, however, it from Mutu Bay in the north. Also recorded from Ogasawara Islands, Formosa and Hongkong.

Breeding. Early in summer, from May to July at Seto.

Parasite. Gastropods, Balcis auratus (S. HIRASE) and B. langfordi (DALL) are often found between spines (HABE, 1952, p. 77). Besides, there are found two crustaceans in association with this species which colored just like the host; one is a crab Echinoecus petiti nipponicus MrYake (MTYake, 1939, p. 90) and the other a shrimp Athanas kominatoensis KUBO, although the latter is often found freely.

32. Echinometra Mathaei (BLAINvILLE). (III ${ }_{3}$, p. 338)

Syn. Echinometra lucunter, YOSHIWARA, 1900, p. 380, 1906, P1. X-3-7. 
Nom. Jap. Naga-uni. (ONODA)

Collecting record. Seto (KomaI et al., 1927, p. 295, as E. lucunter; KomaI \& IKARI, 1929, p. 120; SAKAGUCHI, 1935, p. 14; ONODA, 1936, p. 641).

Material examined. Seto. 5 specimens (No. E-50) and many living specimens. Very common in southern part of Kii Peninsula.

Range. Widely distributed all over the Indo-Pacific region, from Red Sea to Paumotu and Hawaiian Islands, and from Australia to southern Japan. It extends to the southern end of Bôsô Peninsula and Izu Peninsula, but has not so far been found at Misaki.

Breeding. Usually August at Seto.

33. Colobocentrotus Mertensii BRANDT. $\left(\mathrm{III}_{3}\right.$, p. 429$)$

Nom. Jap. Zingasa-uni. (OHshima)

Collecting record. Susami and Kii-ôsima (SAKAGUCHI, 1935, p. 14; IKEDA, 1939, p. 195 ; UTinomi, 1949, p. 55).

Material examined. Sio-no-misaki, at low tide. 2 specimens (H. OGAWA coll.). One specimen from Ogasawara Islands is preserved in the Laboratory (No. E-40).

Range. Known with certainty only from Ogasawara Islands (Type locality) Formosa, Ryukyu, Tokara Islands, Sibusi (Prov. Ôsumi), Kii Prov. and Hatizyô-zima. At Hatizyôzima, this echinoid is familiar among islanders under the name of "Hanzaru" (WATANABE, 1940).

\section{IRREGULARIA}

\section{Order HOLECTYPOIDA}

Family Echinoneidae Wright

34. Echinoneus cyclostomus LESKE。 $\left(\mathrm{IV}_{1}, \mathrm{p} .75\right)$

Nom. Jap. Tamago-uni. (nom. nov.)

Material examined. Ezura, southern coast of Tanabe Bay. A single fossil specimen, $35 \mathrm{~mm}$ long and $27.7 \mathrm{~mm}$ wide (No. R-157). Any living specimen has not been found there (UTinomi, 1953, p. 43).

Range. Cosmopolitan. In the Japanese seas it is known to occur only at Formosa (Yoshiwara, 1900; Hayasaka, 1948), Yaéyama Islands (OHshima, 1947), Tokara Islands (TokiokA, 1953) and Kagosima Bay (MoRTEnsen, 1948).

\section{Order CASSIDULOIDA}

\section{Family Echinolampadidae GRAY}

35. Planilampas sternopetala (A. AGASSIZ \& H. L. ClARK). (IV , p. 298)

Syn. Echinolampas sternopetala, H. L. ClARK, 1917, p. 115; NISIYAMA, 1937, p. 58. 
Nom. Jap. Manzyû̀-uni. (Uтіnomi)

Material examined. Off Minabe, $100-200 \mathrm{~m}$. 6 specimens, $75-90 \mathrm{~mm}$ long (No. R-52) (Utinomi, 1952, p. 15).

Range. Known only from the Japanese seas, from Ôhara, E. of Bôsô Peninsula to off Kagosima Gulf, in depths of ca. $100-500 \mathrm{~m}$. Hitherto not recorded from the Kii region.

\section{Order CLYPEASTROIDA \\ Family Clypeastridae DUNCAN}

36. Clypeaster reticulatus (LINNÉ). $\left(\mathrm{IV}_{2}\right.$, p. 71)

Nom. Jap. Kasuri-takonomakura. (nom. nov.)

Material examined. Minabe. One denuded test, $40 \mathrm{~mm}$ long and $32 \mathrm{~mm}$ wide, collected by M. OzaKI on the beach (No. R-154). (Utinomi, 1952, p. 16).

Range. Widely distributed over the Indo-Pacific, from Red Sea and East African coast to Hawaii and to Formosa. It has not hitherto been recorded from Japan proper.

37. Clypeaster virescens DöDERLEIN. $\left(\mathrm{IV}_{2}\right.$, p. 96)

Nom. Jap. O-takonomakura. (nom. nov.)

Material examined. Off Minabe, $100-200 \mathrm{~m} .14$ specimens, $90-120 \mathrm{~mm}$ in length (No. E-14, E-15) (UTinomi, 1925, p. 15).

Range. Known only from southern Japan and also from Indo-China, in depths of ca. $100-300 \mathrm{~m}$.

38. Clypeaster japonicus DöDERLEIN. $\quad\left(\mathrm{IV}_{2}\right.$, p. 99)

Nom. Jap. Takanomakura.

Collecting record. Seto (TAKI, 1929, p. 157; KomaI \& IKARI, 1929, p. 121). Goza and Katuura (ONODA, 1938, p. 5).

Material examined. Kada. 5 specimens (No. E-12). Seto. Many specimens (No. E-52).

Range. Very common in southern Japan, from the littoral to ca. $75 \mathrm{~m}$.

Breeding. Summer, from July to August (after ONODA).

Commensal. KАTO (1944, p. 278) reported a polyclad Zygantroplana clepeasta KATO from Misaki as occurring on the test.

\section{Family Fibulariidae DUNCAN}

39. Echinocyamus crispus MAzzeTti. $\left(\mathrm{IV}_{2}\right.$, p. 185)

Syn. Echinocyamus elongatus, H. L. ClaRK, 1914, p. 61. 
Nom. Jap. Botan-uni. (nom. nov.)

Material examined. Sioya, Hidaka-gun. One denuded test, $7 \mathrm{~mm}$ long, $5.5 \mathrm{~mm}$ wide and $2.3 \mathrm{~mm}$ high, collected by T. Yamamoto on the beach (No. R-66).

Range. Widely distributed in the Indo-Pacific, from Red Sea to Hawaiian Islands and to southern Japan (Bonin Islands, Korea Strait), in depths of ca. 20 to 564 meters.

40. Fibularia (Fibulariella) acuta Yoshiwara. (IV, p. 219)

Nom. Jap. Mame-uni. (OHsHima)

Collecting record. Gokasyo-wan and Matoya-wan, 10-30m (MiYadi \& MAsur, 1942, p. 122, 125, as Fibularia sp.)

Material examined. Sioya, Hidaka-gun. 10 denuded tests, $6.3-8.5 \mathrm{~mm}$ in length, collected by T. Yamamoto on the beach (No. R-65).

Range. Recorded only from Japan and Malayan seas, in depths of ca. 10-90 m.

Family Laganidae A. AgAssiz

41. Peronella japonica MoRTEnsen. (IV, p. 277)

Syn. Peronella decagonalis, DöDERLEIN, 1885, p. 33.

Laganum decagonalis, YOSHIWARA, 1900, p. 390, 1907, P1. XV-9, 10, 11, 12, 13.

Peronella Lesueuri, ONODA, 1938, p. 11; OHSHIMA, 1947, p. 582. (non A. AGASSIZ).

Nom. Jap. Yotuana-kasipan.

Collecting record. Wakanoura (YosHIWARA, 1900, p. 390; ToKUnAGA, 1903, p. 8, as Laganum decagonalis). Seto (KomaI et al., 1927, p. 295, as L. decagonale; KoMAI \& IKARI, 1929, p. 121, as Peronella lessueuri). Goza and Katuura (ONODA, 1938, p. 11, as $P$. lesueuri). Yura-wan, $12 \mathrm{~m}$ (HABE et al., 1946, p. 8, as P. lesueuri).

Material examined. Hatake-zima (Tanabe Bay). 6 specimens (No. E-8). Tunasirázu (Tanabe Bay). 18 specimens (No. E-10).

$56 \mathrm{~mm}$ long and $49 \mathrm{~mm}$ wide in a medium-sized specimen.

Range. Distributed only in southern Japan and Formosa, from the littoral to ca. $50 \mathrm{~m}$. This is the commonest cake-urchin in the littoral all around the Japanese coast.

Breeding. Summer, from July to August (after ONODA).

Parasite. A gastropod Balcis peronellicola KURODA \& HABE rarely occurs on the peristome (HABE, 1952, p. 77).

42. Peronella pellucida DöDERLEIN. (IV 2, p. 281)

Nom. Jap. Usu-yotuana-kasipan. (nom. nov.)

Material examined. Tanabe Bay. 9 specimens (No. E-13). A medium-sized specimen measures $46 \mathrm{~mm}$ long, $45 \mathrm{~mm}$ wide and $7 \mathrm{~mm}$ high.

Range. Recorded only from Japan (from Sagami Sea to SW. of Kyusyu) in depths of $75-550 \mathrm{~m}$. 
43. Peronella minuta (DE MEIJERE). (IV ${ }_{2}$, p. 295)

Nom. Jap. Mame-yotuana-kasipan. (nom. nov.)

Material examined. Off Tonda. 12 specimens, $6.5-12 \mathrm{~mm}$ in length (No. E-2), Off Tôsima at Seto, $15 \mathrm{~m} .2$ specimens, $7 \mathrm{~mm}$ in length (No. E-30).

Range. Hitherto recorded only from the Philippines (off Jolo, Sulu Archipelago), in depths of ca. $13-35 \mathrm{~m}$.

44. Laganum fudsiyama DöDERLEIN. (IV ${ }_{2}$, p. 338)

Syn. Laganum diploporum, A AGASSIZ \& H. L. CLARK, 1907, p. 128; H. L. CLARK, 1914, p. 48; NISIYAMA, 1937, p. 56.

Nom. Jap. Huziyama-kasipan.

Collecting record. Off Seto, $344 \mathrm{~m}$ (Albatross Station 4965), off Susami, 439$522 \mathrm{~m}$ (Albatross Station. 4966, 4967).

Range. Common in southern Japanese seas, from Kagosima Gulf to Sagami Sea and also to off Kazusa (Japan Sea), in depths of ca. 50-645 m.

\section{Family Scutellidae GrAY}

\section{Scaphechinus mirabilis A. AGASsIz. ( $\mathrm{IV}_{2}$, p. 375)}

Syn. Echinarachnius mirabilis, YosHIWARA, 1900, p. 392 , 1907, Pl. XVI-9, 10; IKEDA, 1940, p. 4.

Nom. Jap. Hasunoha-kasipan.

Collecting record. Seto (Komal et al., 1927, p. 295, as ? E. palma; KomaI \& IKARI, 1929, p. 121). Ise Bay (MTYAd, 1941a, p. 517, 518).

Range. Widely distributed in Japan, from Hakodate to Amakusa.

46. Scaphechinus tenuis (YoshIWARA). (IV, p. 378)

Syn. Echinarachnius tenuis, YOSHIWARA, 1898a, p. 61, 1900, p. 392.

Echinarachnius mirabilis, IKEDA, 1935, p. 202. (in part).

Nom. Jap. Usu-hasunoha-kasipan. (nom. nov.)

Material examined. Off Seto, probably $12 \mathrm{~m} .5$ dead specimens (No. E-1). Hatake-zima (Tanabe Bay), at low tide. 6 specimens (No. E-3).

A smallest specimen measures $13.5 \mathrm{~mm}$ long, $14.8 \mathrm{~mm}$ wide and $2.1 \mathrm{~mm}$ high, and largest one measures $35.4 \mathrm{~mm}$ long, $36.5 \mathrm{~mm}$ wịde and $4.4 \mathrm{~mm}$ high. The genital pores have not appeared outsides in specimens over $24 \mathrm{~mm}$ long, though present insides. According to NIsIYAMA (1940), this may be a variety (or subspecies). of S. mirabilis.

Range. Distributed only in Japanese waters, from Kagosima to Akkesi, from the littoral to ca. $12 \mathrm{~m}$. 
47. Astriclypeus Manni VERRILL. (IV, p. 416)

Nom. Jap. Sukasi-kasipan. (OHsHima)

Collecting record. Goza (ONODA, 1938, p. 8).

Range. Recorded only from southern Japan (from Bôsô Peninsula to Kyusyu) in depths of $0-35 \mathrm{~m}$ and also from China and Cambodja, Indo-China. This is an inland. water form, as not ever found near Seto on the Pacific coast.

Breeding. Summer, from July to August in the Inland Sea (after ONODA).

\section{Order SPATANGOIDA \\ Family Pourtalesiidae LovéN}

48. Pourtalesia laguncula A. Agassiz. $\left(V_{1}\right.$, p. 147)

Nom. Jap. Tokkuri-bunbuku. (OHSHIMA)

Collecting record. Off Kii (A. AgAssiz, 1881, p. 137).

Range. Known only from Japanese and Malayan deep seas, in depths of ca. 220-1370 m.

\section{Family Loveniidae LAMBERT}

49. Lovenia elongata (GRAY). ( $\mathrm{V}_{2}$, p. 97)

Nom. Jap. Hirata-bunbuku. (OHSHIMA)

Collecting record. Suigesi (?=Suiken, Wakayama City) (YosHiwara, 1900, p. 404). Tanabe Bay (MiYadi, 1940a, p. 142).

Material examined. Hatake-zima in Tanabe Bay, in the littoral. 7 specinens (No. E-4).

Range. Widely distributed all over the Indo-Pacific, from Red Sea to southern Japan, as far north as Tokyo Bay. From the littoral down to ca. $90 \mathrm{~m}$.

50. Echinocardium cordatum (PENNANT). ( $\mathrm{V}_{2}$, p. 152)

Nom. Jap. Okame-bunbuku. (OHsHima)

Collecting record. Tanabe Bay (MIYADI, 1941, p. 475, 476).

Material examined. Tanabe Bay, 15-20 m. Many specimens, $12-48 \mathrm{~mm}$ in length (No. E-6, E-9).

Range. Apparently cosmopolitan, from the littoral to ca. $230 \mathrm{~m}$. It is very common in shallow waters of bays or inlets and usually buried in sand.

Family Schizasteridae LAMBERT

51. Schizaster lacunosus (LTNNé). $\left(\mathrm{V}_{2}\right.$, p. 300$)$ 
Syn. Schizaster japonicus, A. AGASsIZ, 1881, p. 202 ; YoshIWARA, 1900, p. 398, 1907, P1. XVII$10 \sim 14$.

Nom. Jap. Bunbukutyagama.

Collecting record. Ago-wan, $20 \mathrm{~m}$ (MIYADI, 1941b, p. 180). Gokasyo-wan, 10$20 \mathrm{~m}$ (Mryadi \& Masui, 1942, p. 122, 124). Kowa-wan, $21 \mathrm{~m}$, Hôza-wan, $23 \mathrm{~m}$ (MtYadi \& Habe, 1946, p. 4, 10, 11). Yura-wan, $12 \mathrm{~m}$ (Habe et al., 1946, p. 6).

Material examined. Tanabe Bay. 2 specimens (No. E-5). Yasima, Prov. Sanuki, $34 \mathrm{~m} .4$ specimens (No. E-63).

Range. From Japan to East Africa and NE. of Australia. In Japan it is very common on sandy bottoms in depths of ca. 5-90 m.

\section{Family Brissidae GRAY}

\section{Brissopsis luzonica (GRAX). ( $\mathrm{V}_{2}$, p. 397)}

Nom. Jap. Bunbuku-modoki. (nom. nov.)

Collecting record. Off Kii (H. L. ClARK, 1917, p. 204). Osaka Bay (MiYad, 1940, p. 12).

Range. Widely distributed all over the Indo-Pacific, from Red Sea to Hawaii and to southern Japan, in depths of 10 to some 1000 meters.

53. Brissus (Allobrissus) Agassizi DöderleIN. ( $\mathrm{V}_{2}$, p. 520)

Syn. Brissus latecarinatus, OHSHIMA, 1947, p. 579. (non LESKE)

Nom. Jap. Ô-bunbuku.

Collecting record. Seto (KomaI et al., 1927, p. 295; KOMAI \& IKARI, 1929, p. 121). Material examined. Seto, at low tide. 3 specimens (No. E-7, E-11) and many living specimens.

Range. Known only from Japan, from Eôsô Peninsula to Amakusa. It lives commonly in shallow waters, buried in sand, and goes down to ca. $10 \mathrm{~m}$.

\section{LITERATURE CITED}

AgAssiz, A. 1881. Report on the Echinoidea. Challenger Report, Zoology. 3 (9), 321 pp., 49 pls. AgAssiz, A. \& ClaRK, H. L. 1907. Hawaiian and other Pacific Echini. Mem. M. C. Z., Harvard Coll., 34 (1), 50 pp., 44 pls.

CrARK, H. L. 1908. Some Japanese and East Indian Echinoderms. Bull. M. C. Z., Harvard Coll., 51 (11), pp. 279-311.

-1912-1917. Hawaiian and other Pacific Echini. Mem. M. C. Z. Harvard Coll., 34 (4), $46(1,2)$.

-_._. 1921. The Echinoderm fauna of Torres Strait: its composition and its origin. Dept. Mar. Biol. Carnegie Inst. of Washington, 10, 223 pp., 38 pls.

DöDERLEIN, L. 1885. Seeigel von Japan und den Liu-Kiu-Inseln. Arch. f. Naturg., 51, pp. $73-112$. 
DöderleiN, L. 1887. Die Japanischen Seeigel, I. Theil. Familie Cidaridae und Saleniidae. 59 pp., 11 pls. Stuttgart.

HABE, T. 1952. Parasitic gastropods found in echinoderms from Japan. Publ. Seto Mar. Biol. Lab., 2 (2), pp. 73-85, pl. 6.

HABE, T. et al., 1946. Benthic communities of the Yura-wan, etc. Rep. Phys. \& Ecol., Kyoto Imp. Univ., No. 56, 14 pp., 2 pls.

HAYASAIA, I. 1948. Notes on the echinoids of Taiwan. Bull. Ocean. Inst. Taiwan, No. 4, 36 pp., 6 pls.

HIRAIWA, Y. 1932. On the dermal structure of a soft-shelled sea-urchin Asthenosoma ijimai Yoshiwara. J. Sci. Hiroshima Univ., Ser. B, Div. 1, 1 (5), pp. 65-80, pls. 1-2.

HIRO, F. 1937. Studies on Cirripedian fauna of Japan, II. Cirripeds found in the vicinity of the Seto Marine Biological Laboratory. Mem. Coll. Sci. Kyoto Imp. Univ., Ser. B, 12 (3), pp. 385-478.

IKEDA, H. 1935. Note on the genus Echinarachnius of Japan. Bult. Sci. Fakul. Terkul., Kjuŝu Imp. Univ., 6 (3), pp. 202-208, pl. 4. (In Japanese with English résumé).

1939. The shape of the test of Colobocentrotus Mertensii Brandt (Echinoidea, Echinometridae). Annot. Zool. Japon., 18 (3), pp. 194-201, pls. 9-10.

-1939a. A new species of Diadema from Japan. Rec. Ocean. Wks. Japan, 10 (2), pp. 165-167, pl. 11.

1940. The fauna of Akkesi Bay: VIII. Echinoidea. Annot. Zool. Japan. 19 (1), pp. 1-8, pls. 1-2.

KATO, K. 1944. Polycladida of Japan. J. Sigen. Ken., 1 (3), pp. 257-319, pls. 26-29.

Komai, T., AKATsUKA, K. \& IKARI, J. 1927. The Seto Marine Biological Laboratory of the Kyoto Imperial University. Its equipment and activities, with remarks on the fauna and flora of the environs. Mem. Coll. Sci. Kyoto Imp. Univ., Ser. B, 3 (3), pp. 281-206, pl. 12.

KomaI, T. \& IKARI, J. 1929. Ditto. (A revised article.) Rec. Ocean. Wks. Japan, 1 (3), pp. 113-129, pls. 27-35.

MrYADI, D. 1940. Marine benthic communities of the Osaka-wan. J. Ocean,, 12 (2), pp. 1-15. 1940a. Marine benthic communities of the Tanabe-wan. Annot. Zool. Japon.; 19 (2), pp. $136-148$.

1941. Indentation individuality in the Tanabe-wan. Mem. Imp. Mar. Obs. Kobe, 7 (4), pp. $471-482$.

1941a. Marine benthic communities of the Ise-wan and the Mikawa-wan. Ibid., 7 (4), pp. 503-524.

1941b. Ecological survey of the benthos of the Ago-wan. Annot. Zool. Japon., 20 (3), pp. 169-180.

MIYADI, D. \& HABE, T. 1946. Benthic communities of the Kowa-wan, Hôza-wan, Kanzaki-wan and Tasikara.wan, along the southern coast of the Kii Peninsula. Rep. Phys. \& Ecol., Kyoto Imp. Univ., No. 57, pp. 1-17, pl. 1.

MIYADI, D. \& MASUI, T. 1942. Comparative studies of the benthic communities of the Matoya-wan and the Gokasyo-wan. Bull. Jap. Soc. Fish., 11 (3), pp, 111-127. (In Japanese)

MrYAKE, S. 1939. Note on crabs of the genus Echinoecus Rathbun living commensally with echinoids (Parthenopidae, Eumedoninae). Annot. Zool. Japon., 18 (2), pp. 83-94.

Mortensen, Th. 1904. The Danish Expedition to Siam 1899-1900. II. Echinoidea (1). Det Kgl. Danske Vidensk. Selsk. Skrifter, 7 Reakke, Naturv. og Mathem. Afd. I, 1, pp. 1-124, pls. 1-7, 1 map.

1928-1951. A monograph of the Echinoidea. Vols. I-V. C. A. Reitzel, Copenhagen.

NISIYAMA, S. 1937. Annotated list of echinoids dredged from the Pacific coast of Tiba Prefecture. Rec. Ocean. Wks. Japan, 9 (1), pp. 47-60.

1940. On the Japanese species of Echinarachnius. Jubilee Publ. Prof. Yabe's 60th Birthday, 2, pp. 803-862, pls. 43-45. 
NisiYama, S. 1942. Recent shallow-water echinoids from the Micronesia. J. Ocean. Soc. Jap., 1 (1/2), pp. 15-24. (In Japanese)

OHshima, H. 1947. Echinoidea. Illustr. Encycl. Fauna of Japan. (Revised edition), pp. 576596. Hokuryûkan, Tokyo.

ONODA, K. 1931. Notes on the development of Heliocidaris crassispina with special reference to the structure of the larval body. Mem. Coll. Sci. Kyoto Imp. Univ., Ser. B, 7 (3), pp. 103-134, pls. $5-7$.

1933. On the orientation of the regular sea-urchin Heliocidaris crassispina. Jap. Jour. Zool., 5 (2), pp. 159-164.

1936. Notes on the development of some. Japanese echinoids with special reference to the structure of the larval body. Ibid., 6 (4), pp. 637-654, pls. 10-14.

1938. Ditto, III. Ibid., 8. (1), pp. 1-13, pls. $1-2$.

RoXAs, H. A. 1928. Philippine littoral Echinoidea. Philip. J. Sci., 36 (2), pp. 243-270, pls. 1-7.

SAKAGUCHI, S. 1935. A catalogue of echinoids occurring in Wakayama Prefecture. Kisyû Dôsyokubutu, 2 (2), pp. 13-16, 1 pl. (In Japanese)

TAKI, Iw. 1929. Notes on a 4-rayed specimen of Clypeaster japonicus Döderlein. Mem. Coll. Sci. Kyoto Imp. Univ., Ser. B, 4 (2), pp. 157-163, pl. 25.

TANAKA, H. 1932. Coeloplana echinicola n. sp. Ibid., 7 (5), pp. 247-250, p1. 19.

TOKIOKA, T. 1953. Invertebrate fauna of the intertidal zone of the Tokara Islands, V. Echinodermata. Publ. Seto Mar. Biol. Lab.. 3 (2), pp. 144-148, pl. 7.

TokUnaGA, S. 1903. On the fossil echinoids of Japan. J. Coll. Sci. Imp. Univ. Tokyo, 17 (12), pp. $1-27$, pls. 1-4.

UTINOMI, H. 1949. Echinoids of tropical element occurring in the waters of Prov. Kii. Nanki Seibutu, 1 (2), pp. 55-56. (In Japanese)

1952. Echinoderms dredged from off Minabe (Record of collections dredged from off Minabe, Prov. Kii, VI). Ibid., 4 (1-2), pp. 9-19. (In Japanese)

1953. Scientific names of echinoids from Japan. Collecting \& Breeding, 15 (2), pp. 43-46. (In Japanese)

WATANABE; S. 1940. Hypodytes rubripinnus (fish) and Diadema setosum (sea-urchin). Ibid., $2(7)$, pp. $251-254$.

Yoshiwara, S. 1897. On two new species of Asthenosoma from the sea of Sagami. Annot. Zool. Japon., 1 (1-2), pp. 5-11, pl. 2.

1898-1900. Japanese echini. (text) Zool. Mag., 10 (1898), pp. 1-8, 73-76, 145-148, $247-250,328-331,439-443 ; 12$ (1900), pp. 379-405. (In Japanese)

1898a. Preliminary notice of new Japanese echinoids. Annot. Zool. Japon., 2 (2), pp. 57-61.

1904-1908. Japanese echini. (plate) Zool. Mag., 16 (1904), pls. I-II; 17 (1905), pls. III-VII ; 18 (1906), pls. VIII-XIII ; 19 (1907), pls. XIV-XIX; 20 (1908), pls. XX-XXI. 